\title{
Firm life cycle and advisory directors*
}

\author{
Ahsan Habib \\ School of Accountancy \\ Massey University \\ Private Bag 102904 \\ Auckland \\ New Zealand \\ Phone: +64 94140800
}

Email: a.habib@massey.ac.nz

\author{
Md. Borhan Uddin Bhuiyan ${ }^{* *}$ \\ School of Accountancy \\ Massey University \\ Private Bag 102904 \\ Auckland \\ New Zealand \\ Phone: +64 94140800
}

Email: m.b.u.bhuiyan@massey.ac.nz

$\&$

\author{
Mostafa Monzur Hasan \\ School of Economics and Finance \\ Curtin University \\ Perth \\ Australia \\ Phone: +61 94140800 \\ Email: monzur.hasan@gmail.com
}

* We thank the Associate Editor and two anonymous reviewers for providing constructive comments. We also acknowledge the helpful comments of the participants in the Australia and New Zealand Academy of Management Conference 2016 in Brisbane, Australia.

** Contact author 


\title{
Firm life cycle and advisory directors
}

\begin{abstract}
This paper investigates whether the presence of advisory directors and monitoring directors varies across firm life cycle stages. We follow a parsimonious life cycle proxy based on the predicted behaviour of operating, investing, and financing cash flows across the different life cycle stages that result from firm performance and the allocation of resources. Using an Australian sample, this study shows that compared to mature stage firms, firms in the introduction, shake-out and decline stages have more advisory directors. With respect to the demand for monitoring directors, we find that compared to mature-stage firms, firms in the introduction, shake-out and decline stages have fewer monitoring directors on the board. We contribute to the literature on boards of directors by documenting that firms choose an optimal board structure based on their economic characteristics.
\end{abstract}

Keywords: Advisory directors; firm life cycle; monitoring directors; Australia 


\section{Introduction}

We examine whether the presence of advisory directors and monitoring directors varies across firm life cycle stages. Economic theory suggests that the board of directors is an important element of the governance structure of the corporation (Adams et al., 2010; Hermalin and Weisbach, 1998, 2003). The board serves two functions: advisory and monitoring (Jensen, 1993; Monks and Minow, 2004). The advisory function requires that directors use their expertise to counsel management in establishing and implementing new and potentially risky strategic initiatives. The monitoring function requires the board to act as a "watchdog" in order to align the incentives of management with the interests of shareholders (Chen, 2008; Demb and Neubauer, 1992). Adams and Ferreira (2007) show that if the advisory and monitoring functions are performed by the same group of directors, then the CEO is unwilling to share information that helps directors to provide advice, since the same information set can also be used for monitoring the CEO. A separation between advisory and monitoring board members is beneficial because it serves as a substitute for a commitment not to use the revealed information against the CEO (Laux and Laux, 2009).

Evidence suggests that a set of firm-level variables determines the characteristics of advisory directors, e.g., professional expertise and experience valuable for strategic decision making, entrepreneurial background, CEO-level experience, advanced degrees, and longer board tenures (Faleye et al., 2013). Evidence also suggests that boards with more advisory directors increase firm value (Coles et al., 2008; Faleye et al., 2013), and earnings persistence (Hsu and $\mathrm{Hu}, 2015$ ). Although insightful, these studies take a static view of advisory boards in that they do not consider the variation in the intensity of board advice during different life cycle stages. We investigate the role of firm life cycle as a determinant of advisory boards and, hence, respond to a call for additional research on this aspect (Bonn and Pettigrew, 2009; Filatotchev and Wright, 2005; Perrault and McHugh, 2015). 
While both advisory and monitoring functions are value additive, Filatotchev and Wright (2005) propose that the advisory role of directors may vary in importance depending upon the phase of a firm's life cycle, because strategic postures and the challenges of strategy implementation also vary across different life cycle stages. For example, firms in the introduction and growth phases of their life cycle may be better served by directors with advisory skills, as these directors can offer legitimacy to the firm that, in turn, attracts other resource providers, such as investors and established suppliers: a strategy that is particularly important for resource-constrained, entrepreneurial firms (Perrault and McHugh, 2015; Withers et al., 2012).

We choose Australia as our setting for investigating the association of life cycle with the presence of advisory boards because of its flexible governance environment. The Australian Securities Exchange (ASX) Corporate Governance Council released 'The Principles of Good Corporate Governance and Best Practice Recommendations' in 2003. The recommendations adopted the 'comply or explain' principle, which allows companies to choose whether to comply with the recommendations, but requires that non-compliance be disclosed in the annual reports. Such 'comply or explain' types of regulatory guideline are designed to overcome the 'one size fits all' criticism by allowing for more flexibility. It should be noted that corporate governance guidelines do not prescribe the composition (size and characteristics) of advisory committees but, instead, are more geared towards the formation and functioning of monitoring committees.

We define advisory directors as independent and/or executive directors (excluding CEOs) who are not members of the monitoring committees, but who serve on the nomination committee, where the firm has a separate nomination committee. If the company has no standing nomination committee, then advisory directors are directors who are not members of the monitoring committees. We include nomination committee members as advisory directors 
because of their role, among others, in the recruitment of directors with appropriate skills, knowledge, and experience required for board functions. ${ }^{1}$

We use a parsimonious life cycle measure proposed by Dickinson (2011) as our primary independent variable. Dickinson (2011) groups firms into five life cycle stages, such as: 'introduction', 'growth', 'mature', 'shake-out' and 'decline', based on the cash flow patterns of firms. Using a sample of 11,251 firm-year observations from 2001 to 2014, we find that, compared to mature stage firms, firms in the introduction, shake-out and decline stages have more advisory directors. With respect to the demand for monitoring directors, we find that compared to mature-stage firms, firms in the introduction, shake-out and decline stages have fewer monitoring directors on the board.

Our study contributes to both the corporate governance and the firm life cycle literature. First, we extend the governance literature by revealing the presence of different levels of advisory directors in different life cycle stages. Prior literature on board formation has generally taken a static view, by proposing a number of firm fundamentals as the determinants of the size and composition of the board (Boone et al., 2007; Linck et al., 2008; Monem, 2013). These studies fail to capture the variation of board composition during different life cycle stages. Huse and Zattoni (2008), use a case study approach on three Norwegian small firms to show evidence that board behaviour changes over the life-cycle phase. They raise a concern over the generalisability of their research findings and call for additional research. We respond to this call. Second, our findings complement a stream of research that documents the importance of organisational life cycle in influencing dividend payout (e.g., DeAngelo et al., 2006; Fama and French, 2001), capital structure (Berger and Udell, 1998), investment decisions (Richardson, 2006), cost of equity (Hasan et al., 2015), corporate risk taking (Habib and Hasan, 2017), tax avoidance (Hasan et al., 2016) and the pricing of accruals and cash flows (Hribar and Yehuda, 2015). Even though these studies 
suggest that firm life cycle has profound implications on corporate decisions and outcomes, surprisingly, board composition during different life cycle stages, in particular the composition of advisory directors, has remained unexplored. Our study fills this void in literature.

The rest of this paper proceeds as follows. The next section discusses existing literature and develops our testable hypotheses. The following section explains the research design and sample selection process. Section 4 presents the results, and the last section concludes.

\section{Literature review and development of hypotheses}

\subsection{Firm life cycle and board composition}

The board of directors is the primary governance mechanism responsible for approving corporate strategies, hiring and firing top executives, ensuring financial reporting integrity, and setting appropriate compensation for CEOs (Adams et al., 2010; Hermalin and Weisbach, 1998, 2003). ${ }^{2}$ The board serves two functions: advisory and monitoring (Jensen, 1993; Monks and Minow, 2004). Adams and Ferreira (2007), Harris and Raviv (2008), Raheja (2005) and Song and Thakor (2006) provide theoretical models for the board's influence over strategy and conclude that the advisory role depends critically on information provided by the CEO. Advisory directors are intimately involved in counselling the CEO when initiating and implementing new and potentially risky strategic initiatives (Daily and Dalton, 1992; Demb and Neubauer, 1992; Filatotchev and Bishop, 2002). Also, the industry-specific skills and expertise of those advisory directors can help mitigate information asymmetries between management and shareholders (Masulis et al., 2012).

The monitoring of management is also very important. The likelihood of selfinterested managerial behaviour necessitates vigilant monitoring by independent or non- 
executive directors, who have no financial interest in the firm. But intense monitoring leads to a detrimental impact on the advisory role compromising the board's ability to create value (Faleye et al., 2011). Finally, intense monitoring can promote managerial myopia by weakening the CEO's perception of board support, which is necessary to encourage investment in risky but value-enhancing ventures, such as corporate innovation (Faleye et al., 2011).

While both advisory and monitoring functions are important, Filatotchev and Wright (2005) propose that the advisory role of directors may vary in importance depending upon the phase of a firm's life cycle. Corporate life cycle theory proposes that firms pass through a series of stages throughout their life cycle, and that the resources, capabilities, strategies, structures and functioning of the firm including functioning of the board vary significantly with stages of development (Miller and Friesen, 1980, 1984; Quinn and Cameron, 1983). Assessing the life cycle stages is difficult, as each individual firm is composed of many overlapping, but distinct, product life cycle stages. Previous research generally suggests a four or five stage life cycle model. For example, Quinn and Cameron (1983) propose that firms progress through entrepreneurial, growth, maturity, and decline phases. Dickinson (2011) argues that cash flows capture differences in a firm's profitability, growth and risk and, hence, that one may use the cash flow from operating (OCF), investing (INVCF) and financing (FINCF) activities to group firms into five life cycle stages: 'introduction', 'growth', 'mature', 'shake-out' and 'decline'. Firms in the introduction stage suffer from negative cash flows because of a lack of established brands, and entrepreneurs' knowledge deficits about potential revenues and costs. During the growth and mature stages profit margins are maximised, because increases in investment and efficiency generate positive cash flows. Shake-out stage firms experience declining sales, earnings, and operating cash flows. 
Finally, during the decline stages of the firm life cycle, declining growth rates lead to declining prices and, hence, negative cash flows.

\subsection{Advisory directors and firm life cycle}

With respect to board composition across life cycle stages, we posit that firms in the introduction stage face the critical challenge of garnering support from external stakeholders. This task is difficult if there is an absence of a proven reputation for succeeding in a competitive environment (Ashforth and Gibbs, 1990; Petkova et al., 2008). These firms, in particular, are resource-constrained and, require advice for procuring resources to execute strategies. It is conjectured that firms in the introduction stage may be better served by directors with advisory skills. These directors can also offer legitimacy to the firm, to attract other resource providers, such as investors, and established suppliers (Perrault and McHugh, 2015; Withers et al., 2012).

At the growth stage, firms actively seek new investment opportunities to expand their operations across business segments and geographic boundaries and require substantial investment in strategic projects (Jawahar and McLaughlin, 2001). A firm in the growth stage is likely to replace the founder of the business by professional managers and develop a more formalised organisational structure (Bonn and Pettigrew, 2009). Operating activities at the growth stage require more internal control, coordination and integrated decision-making methods. Advisory directors, by dint of their skills, expertise and social connections, can assist growth firms in coordinating control activities, and in formulating and implementing strategy for expanding operations to assist further growth and development. Appointing more advisory directors in the growth stage also helps firms in gaining legitimacy, thereby assuring external stakeholders of the viability of the organisation (Bonn and Pettigrew, 2009; Perrault and McHugh, 2015). 
Firms' transition in the shake-out stage is manifested by declining sales, earnings, and operating cash flows (Dickinson, 2011). As a firm slips to the shake-out stage, management often reassess the strategies currently in place to deal with the different stakeholder groups (Jawahar and McLaughlin, 2001). To ensure survival and regain market share, management of the shake-out stage is likely to consider such strategies as product-redevelopment, mergers, downsizing, and layoffs. Kazanjian (1988) also notes the importance of developing secondgeneration or completely new products to spur growth as a survival strategy. However, given the highly competitive marketplace, downgraded resources, and other detrimental changes in the external environment, initiating and implementing survival strategies for shake-out stage firms is very challenging. This prompts management to resort to advisory directors with strategic expertise, who can counsel management in establishing and implementing new and potentially risky strategic initiatives to keep the company healthy and competitive. The preceding discussion, therefore, predicts a strong demand for advisory directors in the shakeout stage as well.

Conventional operating activities are absent in the declining stage of a firm and the board size tends to become smaller as the declining stage progresses (Daily and Dalton, 1994; Gilson, 1989, 1990). Firms focus on 'retrenchment' and 'recovery response' activities at the declining stage. Barker and Mone (1994) suggest that highly distressed firms often sell off their best assets to raise cash. While such an action can have a negative effect on corporate efficiency, Robbins and Pearce (1992) argue that retrenchment leads to a more successful turnaround. However, choosing a poor downsizing strategy, or implementing the chosen strategy poorly, could further push a firm into decline (Sutton et al., 1986). Cameron et al. (1991) criticise most downsizing activities for being solely focused on quick work force reduction to reduce costs, as this may be the least effective method of downsizing. A declining firm requires a high level of strategic reorientation and the advisory director is the 
best person to assist the CEO to implement an effective strategy skilfully. Bonn and Pettigrew (2009) suggest that firms can address declining stage challenges through persuading directors to stay on board, or appointing new directors, in order to implement or reorient business strategies. Therefore, the necessity for an advisory director is inevitable, even in the declining stage.

Since Dickinson (2011) classifies firm life cycle into five stages, empirical execution requires one of the stages to be incorporated into the intercept. We consider the mature stage as our benchmark life cycle stage. Firms in the mature stage are well-established and tend to be larger than at any other stage of the firm life cycle (Dickinson, 2011). The mature stage of the firm life cycle generally results in a shift toward efficiency maximisation, reduced uncertainty and declining investment expenditure relative to the growth phase, along with greater capital distribution to shareholders (Barclay and Smith, 2005; Habib and Hasan, 2015). Profit maximisation in this stage is evidenced by growth in profitability (e.g., return on net operating assets) and in retained earnings, leading to higher and sustained dividend payouts (DeAngelo et al., 2006). In this stage, decision-making becomes standardised, less strategic and proactive, and more risk-adverse than in any other stage (Miller and Friesen, 1984). Consequently, boards in mature organisations are not directly involved in strategy formulation (Stiles and Taylor, 2001). Furthermore, availability of resources and established connections with key stakeholders reduce the resource providing role of advisory directors. At this stage, the value protection role of corporate governance becomes particularly important (Filatotchev et al., 2006). Therefore, we expect the demand for advisory directors to decrease during the mature stage of the firm life cycle.

We hypothesise as follows: 
H1. The need for advisory directors varies across life cycle stages, with firms in the introduction, growth, shake-out, and decline stages demanding more advisory directors, when compared to the mature stage of the firm life cycle.

\subsection{Monitoring directors and firm life cycle}

At the introduction stage of the life cycle, firms generate negative cash flows because of knowledge deficit about potential revenues and costs (Dickinson, 2011). Firms at this stage seek directors who can provide resources for strategy formulation and execution. The demand for monitoring directors is less, because of the absence of free cash flow-induced agency conflicts. The demand for monitoring directors in the growth stage is ex-ante unclear. Firms at this stage might require fewer monitoring directors, because of their focus on innovation, brand development, and organisational growth: activities that are better served by advisory directors. However, growth firms also are likely to suffer from growth-oriented agency conflicts requiring monitoring by directors. At the shake-out and declining stages, firm cash flows decline, thereby minimising the free cash flow-induced agency costs and, hence, the demand for monitoring directors. Moreover, monitoring directors withdraw their directorial positions from these firms, to retain their 'elite' reputation in the job market (D'Aveni, 1990). At this stage, firms try to reinvent their business strategy to rebound back to profitability. A tighter monitoring by boards could become a constraint for the reinvention process (Francis and Smith, 1995).

Mature firms focus more on formal controls, budgets and performance measures, and earning adequate profit margins by their smooth and efficient functioning in a competitive market (Bonn and Pettigrew, 2009). However, mature firms are exposed to the agency costs of free cash flows (Jensen, 1986). As investment opportunities decline while cash flows increase, managers of mature firms tend to invest in negative net present value projects to 
prevent retrenchment. Therefore, at this stage, the value protection role of corporate governance becomes particularly important and, mature firms devote more resources to value preservation rather than value creation (O'Connor and Byrne, 2015). Filatotchev et al. (2006) document that as firms mature, the resource or strategy role of governance becomes less relevant, while the monitoring or control function becomes more important. Therefore, we expect the demand for monitoring directors to increase during the mature stage of the firm life cycle. The preceding discussion, therefore, leads to the following hypothesis:

H2. The need for monitoring directors varies across firm life cycle stages, with firms in the introduction, shake-out, and decline stages demanding fewer monitoring directors, when compared to the mature stage of the firm life cycle.

\section{Research design and sample selection}

\subsection{Model}

We estimate the following models to test the association between firm life cycle stages and the presence of advisory directors and monitoring directors.

$$
\begin{aligned}
& \text { ADVDIR }_{i t}=\gamma_{0}+\sum_{\gamma=1}^{4} \mathrm{LC}_{-} \mathrm{DUM}_{\mathrm{it}}+\gamma_{5} \mathrm{SIZE}_{\mathrm{it}}+\gamma_{6} \mathrm{LEV}_{\mathrm{it}}+\gamma_{7} \mathrm{MTB}_{\mathrm{it}}+\gamma_{8} \mathrm{PPE}_{\mathrm{it}}+\gamma_{9} \mathrm{BSIZE}_{\mathrm{it}}+\gamma_{10} \mathrm{INDPEN}_{\mathrm{it}}+ \\
& \text { INDUSTRY_FE }+ \text { YEAR_FE }+\varepsilon_{i t}
\end{aligned}
$$

Where, ADVDIR is the proportion of advisory directors. We define advisory directors as independent and/or executive directors (excluding CEOs) who are not members of the monitoring committees, but who serve on the nomination committee, where the firm has a separate nomination committee. If the company has no standing nomination committee, then advisory directors are directors who are not members of the monitoring committees. We scale the number of advisory directors by total board size and use this continuous measure, ADVDIR, as our main empirical construct. 
Our main variable of interest is LC_DUM and we expect the coefficient to vary across life cycle stages with respect to the demand for advisory directors and monitoring directors. We follow the life cycle model proposed by Dickinson (2011), who argues that cash flows capture differences in a firm's profitability, growth and risk and, hence, that one may use the cash flow from operating (OCF), investing (INVCF) and financing (FINCF) activities to group firms into life cycle stages, such as: 'introduction', 'growth', 'mature', 'shake-out' and 'decline'. ${ }^{3}$ The classification is based on the following cash flow pattern:

(1) Introduction (INTRO): $\quad$ if $\mathrm{OCF}<0$, INVCF $<0$ and FINCF $>0$;

(2) Growth (GROWTH): $\quad$ if $\mathrm{OCF}>0, \mathrm{INVCF}<0$ and FINCF $>0$;

(3) Mature (MATURE): $\quad$ if $\mathrm{OCF}>0$, INVCF $<0$ and FINCF $<0$;

(4) Decline (DECLINE): $\quad$ if $\mathrm{OCF}<0$, INVCF $>0$ and FINCF $\leq$ or $\geq 0$; and

(5) Shake-out (SHAKE-OUT): the remaining firm years.

We expect the demand for advisory directors to be higher during the introduction, growth, shake-out and decline stages of their life cycle, while lower during the mature stage. We include a number of firm characteristics that are likely to affect the proportion of advisory directors. The demand for advisory directors should decrease for larger firms as these firms have fewer growth opportunities and hence less need for advising requirements. Large firms may require more monitoring instead of advising because of their complexities and resource availability. Directors of large firms are more likely to focus on monitoring large firms as the reputational consequences for oversight failures can be quite damaging (Faleye et al., 2013). We use the natural logarithm of total assets as our proxy for size (SIZE). We use the ratio of long-term debt to total assets (LEV) as a measure of dependence on external financial resources and expect a positive association with the demand for advisory directors. ${ }^{4}$ Growth firms (MTB - measured as market value of equity divided by book value of equity), need more advisory services, therefore, a positive coefficient is expected. We use the ratio of property, plant, and equipment (PPE) to total assets as a measure of asset structure 
and expect this to be negatively related to the demand for advisory directors (Coles et al., 2008). The probability of an individual director serving in an advisory role increases with board size (number of members on the board) (BSIZE) but decreases with a larger proportion of independent directors (number of independent directors to board size) (INDPEN) on the boards, since independent directors are more likely to serve on the monitoring committees. ${ }^{5}$ We include industry and year dummies to control for industry and fiscal year effects, respectively.

Finally we estimate the following regression specification to test $\mathrm{H} 2$, i.e., the association between firm life cycle and the presence of monitoring directors.

$$
\begin{aligned}
& \text { MONDIR }_{\text {it }}=\gamma_{0}+\sum_{\gamma=1}^{4} \mathrm{LC}_{-} \mathrm{DUM}_{\mathrm{it}}+\gamma_{5} \mathrm{SIZE}_{\mathrm{it}}+\gamma_{6} \mathrm{LEV}_{\mathrm{it}}+\gamma_{7} \mathrm{MTB}_{\mathrm{it}}+\gamma_{8} \mathrm{PPE}_{\mathrm{it}}+\gamma_{9} \mathrm{BSIZE}_{\mathrm{it}}+\gamma_{10} \mathrm{INDPEN}_{\mathrm{it}}+ \\
& \text { INDUST RY_FE+YEAR_FE }+\varepsilon_{\text {it }}
\end{aligned}
$$

MONDIR is the ratio of the number of independent directors who are members of the audit (AC) and/or remuneration committees (RC) to the total board size. Other variables are defined as before. We expect the presence of monitoring directors to be higher during the mature stage of the firm life cycle, while lower during the introduction, shake-out and decline stages. However, this prediction may not gain empirical support, as corporate governance guidelines require the monitoring committees to be composed of a majority, if not all, independent directors, providing less cross-sectional variation for our regression estimations. To take into account the time series and cross sectional dependence in the error terms of our regression, in all regression models, we calculate t-statistics using standard errors that are clustered by both firm and year (Gow et al., 2010; Petersen, 2009).

\subsection{Sample selection}

We collect director-level data from the Securities Industry Research Centre of AsiaPacific (SIRCA). The 'Corporate Governance Database' of SIRCA identifies advisory 
directors, who are defined as directors and are not members of the monitoring committees (namely audit committees, compensation committees, and nomination committees). The SIRCA database covers governance data for 1500 listed Australian firms. Our sample period spans 2001 to 2014. We begin with 2001 because corporate governance data from SIRCA first became available in 2001. We collect financial statements data from Compustat Global file. Our initial sample is 18,239 non-financial firm-year observations with non-missing data to calculate firm life cycle following the Dickinson (2011) measure. ${ }^{6}$ We then drop 6,382 firm-year observations with missing director-level information in SIRCA to identify advisory and monitoring director status. Missing control variables (a total of 606 firm-year observations) reduced the sample to 11,251 firm-year observations. All the continuous variables are winsorised at the $1^{\text {st }}$ and $99^{\text {th }}$ percentiles to mitigate the undesirable influence of outliers.

\section{Results}

\subsection{Descriptive statistics}

Table 1 presents descriptive statistics for the variables included in the regression estimates. Panel A reports pooled descriptive statistics for the dependent, independent and control variables, Panel B presents the industry distribution of the sample observations, and Panel C presents the life cycle-wise mean difference of advisory and monitoring directors. With respect to the distribution of observations across life cycle stages, we find that the highest (lowest) percentage of firm-year observations belong to the introduction (INTRO) (decline (DECLINE)) stages of the life cycle (32.5\% and $8.7 \%$ respectively). Pooled descriptive statistics at the firm-level reveal that, on average, advisory directors (ADVDIR) constitute $48.6 \%$ of the total directors, with an interquartile range of $25 \%$ to $66.7 \%$. Our definition of ADVDIR includes both independent advisory directors (ADVDIR_IND) and executive advisory directors (ADVDIR_EXEC). The respective proportions are $25.9 \%$ and $29.4 \%$. The 
average proportion of MONDIR is $29 \%$. Interestingly we find that $17.3 \%$ of directors serve on both the advisory and the monitoring boards (BOTHDIR). All the director-level variables exhibit considerable variation among firms, thereby supporting the view that the composition of different categories of directors varies across firms (optimal choice theory). Average board size is six, with $71 \%$ of the directors serving in the capacity of independent director. Our sample firms are low-leveraged (average debt to asset ratio of 10.8\%) but high growth firms (a mean MTB ratio of 2.68). PPE is $35.2 \%$ of total assets.

Panel B, Table 1 shows that $33 \%$ of the sample observations belongs to the materials industry (ASX distribution as retrieved from Compustat Global is 36\%) followed by the industrials (16\%) (ASX distribution as retrieved from Compustat Global is 13\%) and consumer discretionary (14\%) (ASX distribution as retrieved from Compustat Global is $11 \%)$

\section{[TABLE 1 ABOUT HERE]}

Table 2 reports the pair-wise comparison of ADVDIR, MONDIR, and BOTHDIR, for different life cycle stages. We perform an ANOVA test followed by Tukey's HSD (honest significant difference) method to determine whether the means of the proportions of different categories of directors for the various pair-wise relationships are significantly different from each other. This table shows that the means for ADVDIR decrease significantly from the INTRO to the remaining life cycle stages (e.g., from 0.597 in the INTRO stage to 0.364 in the MATURE stage). The proportions significantly increase from the MATURE to the SHAKEOUT stage (0.364 versus 0.51$)$, from the MATURE to the DECLINE stage (0.364 versus 0.611), and from the SHAKE-OUT to the DECLINE stage (0.51 to 0.611). The results, therefore, support the theoretical argument that firms in the mature stage have the lowest proportion of ADVDIR. The proportion of MONDIR decreases significantly from the MATURE to the SHAKE-OUT stage and from the MATURE to the DECLINE stage, but 
increases significantly from the INTRO to the MATURE stage. The test result provides support for the hypothesis that the demand for monitoring directors is highest during the mature stage of the life cycle. The proportion of BOTHDIR decreases significantly from MATURE to SHAKE-OUT, MATURE to DECLINE, SHAKE-OUT to DECLINE, GROWTH to SHAKE-OUT but increases significantly from INTRO to GROWTH of the life cycle.

\section{[TABLE 2 ABOUT HERE]}

\subsection{Correlation Analysis}

Table 3 presents the correlation analysis. Consistent with our expectation, ADVDIR is significantly and positively correlated with INTRO, SHAKE-OUT and DECLINE stages of the firm life cycle (coefficients $0.24,0.03 \quad 0.12$ respectively, $\mathrm{p}<0.01$ ), while this is significantly negatively correlated with GROWTH and MATURE stages (coefficient -0.14 and -0.22 respectively, $\mathrm{p}<0.01)$. The correlation matrix also suggests that firms in the GROTWH and MATURE stages are positively correlated $(\mathrm{p}<0.01)$ with MONDIR, whereas firms in the INTRO and DECLINE stages are negatively correlated $(\mathrm{p}<0.01)$ with MONDIR. The correlation between BOTHDIR and MATURE is significantly positive $(p<0.01)$ while that with INTRO is significantly negative $(\mathrm{p}<0.01)$.

\section{[TABLE 3 ABOUT HERE]}

\subsection{Regression results}

Table 4, presents the regression results for Equation (1). We use the MATURE stage as the benchmark, and report results for all advisory directors (ADVDIR) (column 1), independent advisory directors only (ADVDIR_IND) (column 2) and non-independent advisory directors (ADVDIR_EXEC) (column 3). The coefficients on INTRO, SHAKE-OUT 
and DECLINE are positive and significant $(0.047, \mathrm{p}<0.01,0.027, \mathrm{p}<0.05$ and $0.054, \mathrm{p}<0.01$ respectively). These results are consistent with H1. Nonetheless, the coefficient on GROWTH is insignificant, implying that growth and mature stages are statistically indistinguishable. Among the control variables, we find that larger firms, firms with more tangible asset structure and more independent directors, demand fewer advisory directors. Firms with greater board size, on the other hand, demand more advisory directors. Column (2) presents the regression results for the association between firm life cycle and independent advisory directors. Results are quite similar to those reported in column (1) (e.g., the coefficients on INTRO, SHAKE-OUT, and DECLINE are 0.037, 0.024, and 0.039 respectively, $\mathrm{p}<0.01)$. In column (3) we report results using executive advisory directors as the dependent variable. We find the coefficient on INTRO to be positive and significant $(0.014, \mathrm{p}<0.01)$, suggesting that firms in the introduction stage of their life cycle demand more independent and executive advisory directors. The coefficients on GROWTH and DECLINE are insignificant, and that on SHAKE-OUT is significantly negative $(-0.019$, $\mathrm{p}<0.01)$

\section{[TABLE 4 ABOUT HERE]}

Table 5 presents regression results for $\mathrm{H} 2$, i.e., the association between firm life cycle and the demand for monitoring directors. We find evidence that the demand for monitoring directors is weaker for firms in the INTRO $(-0.038, \mathrm{p}<0.01)$, SHAKE-OUT $(-0.020, \mathrm{p}<0.10)$ and DECLINE $(-0.056, \mathrm{p}<0.01)$ stages of their life cycles when compared to the MATURE stage of their life cycle (column 1). This evidence is consistent with H2. However, coefficient on GROWTH is statistically insignificant, suggesting that growth and mature stages are statistically indistinguishable. Among the control variables, firms with a larger PPE and higher leverage demand more monitoring directors. From a regulatory perspective, directors serving on the monitoring committees (primarily $\mathrm{AC}$ and $\mathrm{RC}$ ) must be independent outside 
directors with no financial ties with the companies (ASX Corporate Governance Principles and Recommendations, 2010). It is, therefore, not surprising to see a positive and significant coefficient on INDPEN. The coefficient on BSIZE is negative implying that larger boards have less monitoring directors.

\section{[TABLE 5 ABOUT HERE]}

\subsubsection{The proportion of monitoring directors to advisory directors}

In column (2) we report results using the proportion of monitoring directors to advisory directors (MONDIR/ADVDIR) as the dependent variable. This test tells us which of the two functions is more important at any one time. Consistent with our findings on $\mathrm{H} 2$, we document that the monitoring function is less important than the advisory function in the INTRO (-0.257, p<0.01), SHAKE-OUT $(-0.193, \mathrm{p}<0.01)$ and DECLINE $(-0.290, \mathrm{p}<0.01)$ stages when compared to the MATURE stage of the firm life cycle.

\subsubsection{Directorships on both the advisory as well as the monitoring committees}

Our sample consists of directors who serve in both advisory and monitoring capacities (a total of 3,855 firm-year observations). It is intuitive to argue that directors are not appointed to perform an exclusive role, e.g., either advisory or monitoring only. Instead many directors are appointed to perform both roles, and it is most likely that such directors will be found across all life cycle stages. Column (3) in Table 5 shows that the coefficients on the INTRO $(-0.028, \mathrm{p}<0.05)$, SHAKE-OUT $(-0.028, \mathrm{p}<0.05)$ and DECLINE $(-0.026, \mathrm{p}<0.10)$ stages of the firm life cycle are negative using the MATURE stage as the benchmark. This corroborates the hypothesis that firms at different life cycle stages have different demands for advisory and monitoring directors. 


\section{Conclusions}

This paper examines the presence of advisory directors as well as monitoring directors at different stages of the firm life cycle. Fama and Jensen (1983) argue that a firm structures its board in response to its needs to obtain unbiased and expert information. Existing research examines the link between the strategic role of advisory directors and its effects on acquisitions, corporate innovation and firm value. Despite the widespread belief that boards should mirror the firm's external environment (Pfeffer and Salancik, 1978) and that environmental changes should lead to board changes, the demand for advisory board members at different stages of the firm life cycle is still unexplored. Using the Australian regulatory setting, we provide evidence that firms in the introduction, shake-out and decline stages of the firm life cycle utilise more advisory directors, when compared to the mature stage. Further, we examine the presence of monitoring directors during the different stages of the firm life cycle and find evidence that the demand for monitoring directors is less in the introduction, shake-out and decline stages of the firm life cycle, when compared to the mature stage. Our analysis also reveals that demand for advisory directors and monitoring directors is statistically indistinguishable in growth and mature stages. Our findings lead to a deeper and more complete understanding of an aspect of organisational complexity that the 'one size fits all' nature of corporate governance guidelines fails to address.

Our research findings should be beneficial to the regulators, policy makers and professional and academic research. To date, Corporate Governance Best Practice Code mostly emphasizes on the necessity of a monitoring director without recognizing the contribution of an advisory role. Our findings evidence that the necessity of advisory directors is equally important parallel to the monitoring director across the different stage of firm life cycle. Standard setters could encourage firms to develop corporate governance structure accommodating advisory directors to maintain a balance between both advisory and 
monitoring directors. Academic research can examine the beneficial role of advisory directors to overcome distress operating performance and understand their contribution towards effective investment decision,

Our paper is not without limitations. First, we have measured advisory directors as those who don't serve on the monitoring committees. However, such a measure may fail to capture the individual characteristics that could impact the demand for such directors across different life cycle stages. Future research may enrich this measurement by looking into the detailed biographical discussion about the directors. Second, the sample selection bias is obviously a concern. We used director-level information retrieved from SIRCA which covers the top 1500 Australian companies. These are large companies with different demand for advisory and monitoring directors. Extending this study to mid and small-sized companies may shed additional insights into how life cycle stages shape the demand for advisory and monitoring directors. 


\section{Notes}

1. We consider directors serving on the nomination committees as advisory directors, because the Australian Securities Exchange Corporate Governance Principles and Recommendation 2010 outline the following activities of nomination committees as advisory in nature: (a) board succession planning generally (b) induction and continuing professional development programs for directors (c) the development and implementation of a process for evaluating the performance of the board, its committees and directors (d) the process for recruiting a new director, including evaluating the balance of skills, knowledge, experience, independence and diversity on the board and, in the light of this evaluation, preparing a description of the role and capabilities required for a particular appointment (e) the appointment and re-election of directors; and (f) ensuring there are plans in place to manage the succession of the CEO and other senior executives.

2. A substantial volume of academic research has investigated different facets of the board of directors, including factors that determine the formation and composition of boards and their sub-committees, and how boards affect firm's operating and market performance (Baker and Gompers, 2003; Boone et al. 2007; Linck et al., 2008; Raheja, 2005). Boone et al. (2007), for example find that board size and independence increase as firms grow and diversify over time. They also show that board size - but not board independence, reflects a trade-off between the firm-specific benefits and costs of monitoring. Some other studies investigating the board composition include Coles et al. (2008), Duchin et al. (2010), Ferreira et al. (2009), Guest (2008), Lehn et al. (2009), Monem (2013) and Prevost et al. (2002).

3. Anthony and Ramesh (1992) provide one of the first empirical procedures for classifying firms into different life cycle stages. However, we do not use their method for three reasons. These include (i) The life cycle classification based on (Anthony and Ramesh, 1992) requires a five year history of variables, removing true "introduction stage" firms from the sample. Thus, no data (and, as such, no meaningful analyses) on introduction stage firms are available. (ii) Dickinson (2011) has shown that life cycle classification based on the Anthony and Ramesh (1992) procedure leads to an erronous classification of the stage of firms in the life cycle. (iii) This classification procedure is 'ad hoc' and relies on portfolio sorts to classify the firm into different life cycle stages.

4. Lenders are likely to demand more advisory directors on the board to avoid future investment expenditures due to covenant violations (Chava and Roberts, 2008). Armstrong et al. (2010) posit that debt providers often emphasize on the advising role of the boards as firms seek expert advice on investment decisions.

5. Large firms have diversified and complex operations which requires bigger boards and hence including both variables in the same model may not be warranted. However, since our outcome variable is related to board composition, inclusion of board size along with firm size is justifiable. Boone et al. (2007) and Guest (2009) also include firm size and board size in the same regression model.

6. This number is smaller than the ASX population (retrieved from Compustat Global) of 21,225 firm-year observations as reported in Panel B of Table 1, because we need non-missing cash flow data to calculate the life cycle measure. Some of the observations on the ASX sample retrieved from COMPUSTAT does not have the required cash flow data. 


\section{References}

Adams R and Ferreira D (2007) A theory of friendly boards. The Journal of Finance 62: 217-250.

Adams R, Hermalin B and Weisbach M (2010) The role of boards of directors in corporate governance: a conceptual framework and survey. Journal of Economic Literature 48: 58-107.

Anthony J and Ramesh K (1992) Association between accounting performance measures and stock prices: A test of the life cycle hypothesis. Journal of Accounting and Economics 15: 203-227.

Armstrong CS, Guay, WR and Weber JP (2010) The role of information and financial reporting in corporate governance and debt contracting. Journal of Accounting and Economics 50:179234.

Ashforth B and Gibbs B (1990) The double-edge of organizational legitimation. Organization Science 1: $177-194$

ASX (2003) Principles of Good Corporate Governance and Best Practice Recommendations, Australian Stock Exchange Corporate Governance Council, Sydney: $1-75$.

ASX (2010) Corporate Governance Principles and Recommendations with 2010 Amendments, Australian Stock Exchange Corporate Governance Council, Sydney: 1-52.

Baker M and Gompers P (2003) The determinants of board structure at the initial public offering. Journal of Law and Economics 46: 569-598.

Barclay MJ, and Smith CW (2005) The capital structure puzzle: The evidence revisited. Journal of Applied Corporate Finance 17: 8-17.

Barker V and Mone M (1994) Retrenchment: Cause of turnaround or consequence of decline? Strategic Management Journal 15: 395-405.

Berger A and Udell G (1998) The economics of small business finance: The roles of private equity and debt markets in the financial growth cycle. Journal of Banking and Finance 22: 613-673.

Bonn I and Pettigrew A (2009) Towards a dynamic theory of boards: An organisational life cycle approach. Journal of Management and Organization 15: 2-16.

Boone AL, Field L, Karpoff J and Raheja C (2007) The determinants of corporate board size and composition: An empirical analysis. Journal of Financial Economics 85: 66-101.

Cameron KS, Freeman SJ and Mishra AK (1991) Best practices in white-collar downsizing: Managing contradictions. The Executive 5: 57-73.

Chava S and Roberts MR (2008) How does financing impact investment? The role of debt covenants. The Journal of Finance 63: 2085-2121.

Chen D (2008) The monitoring and advisory functions of corporate boards: Theory and evidence. (Working Paper). Baltimore, Maryland: University of Baltimore. Available at ssrn.com/abstract $=1327066$.

Coles JL, Daniel ND and Naveen L (2008) Boards: Does one size fit all? Journal of Financial Economics 87: 329-356.

Daily CM and Dalton DR (1992) The relationship between governance structure and corporate performance in entrepreneurial firms. Journal of Business Venturing 7: 375-386.

Daily CM and Dalton DR (1994) Bankruptcy and corporate governance: The impact of board composition and structure. Academy of Management Journal 37: 1603-1617.

D'Aveni RA (1990) Top managerial prestige and organizational bankruptcy. Organization Science 1: 121-142.

DeAngelo H., DeAngelo L and Stulz RM (2006) Dividend policy and the earned/contributed capital mix: a test of the life-cycle theory. Journal of Financial Economics 81: 227-254.

Demb A and Neubauer FF (1992) The corporate board: Confronting the paradoxes. Long Range Planning 25: 9-20.

Dickinson V (2011) Cash flow patterns as a proxy for firm life cycle. The Accounting Review 86: 1969-1994.

Duchin R, Matsusaka JG and Ozbas O (2010) When are outside directors effective? Journal of Financial Economics 96: 195-214.

Faleye O, Hoitash R and Hoitash U (2011) The costs of intense board monitoring. Journal of Financial Economics 101: 160-181. 
Faleye O, Hoitash R and Hoitash U (2013) Advisory directors (Working Paper). Boston, MA: Northeastern University and Waltham, MA: Bentley University. Available at SSRN 1866166.

Fama EF and French K R (2001) Disappearing dividends: changing firm characteristics or lower propensity to pay? Journal of Financial Economics 60: 3-43.

Fama EF and Jensen MC (1983) Separation of ownership and control. Journal of Law and Economics 26: 301-325.

Filatotchev I and Bishop K (2002) Board composition, share ownership, and 'underpricing' of UK IPO firms. Strategic Management Journal 23: 941-955.

Filatotchev I and Wright M (2005) The life cycle of corporate governance: Cheltenham: Edward Elgar.

Filatotchev I, Toms S and Wright M (2006) The firm's strategic dynamics and corporate governance life-cycle. International Journal of Managerial Finance 2: 256-279.

Francis J and Smith A (1995) Agency costs and innovation some empirical evidence. Journal of Accounting and Economics 19: 383-409.

Gilson SC (1989) Management turnover and financial distress. Journal of Financial Economics 25: 241-262.

Gilson SC (1990) Bankruptcy, boards, banks, and blockholders: Evidence on changes in corporate ownership and control when firms default. Journal of Financial Economics 27: 355-387.

Gow ID, Ormazabal G and Taylor DJ (2010) Correcting for cross-sectional and time-series dependence in accounting research. The Accounting Review 85: 483-512.

Guest PM (2008) The determinants of board size and composition: Evidence from the UK. Journal of Corporate Finance 14: 51-72.

Guest PM (2009) The impact of board size on firm performance: evidence from the UK. The European Journal of Finance, 15: 385-404.

Habib A and Hasan MM (2017). Firm life cycle, corporate risk-taking and investor sentiment. Accounting \& Finance 57: 465-497.

Harris M and Raviv A (2008) A theory of board control and size. Review of Financial Studies 21:1797-1832.

Hasan MM, Hossain M, Cheung A and Habib A (2015) Corporate life cycle and cost of equity capital. Journal of Contemporary Accounting and Economics 11: 46-60.

Hasan, M. M., Al-Hadi, A., Taylor, G., and Richardson, G. (2016). Does a firm's life cycle explain its propensity to engage in corporate tax avoidance? European Accounting Review, Forthcoming.

Hermalin BE and Weisbach MS (1998) Endogenously chosen boards of directors and their monitoring of the CEO. American Economic Review 88: 96-118.

Hermalin BE and Weisbach MS (2003) Boards of directors as an endogenously determined institution: a survey of the economic literature. Economic Policy Review 9:7-26.

Hribar P and Yehuda N (2015). The mispricing of cash flows and accruals at different life-cycle stages. Contemporary Accounting Research 32: 1053-1072.

Hsu PH and Hu X (2015) Advisory board and earnings persistence. Journal of Accounting, Auditing and Finance 31: 134-1571-24.

Huse M and Zattoni A (2008) Trust, firm life cycle, and actual board behavior: Evidence from" one of the lads" in the board of three small firms. International Studies of Management \& Organization 38: 71-97.

Jawahar I and McLaughlin GL (2001) Toward a descriptive stakeholder theory: An organizational life cycle approach. Academy of Management Review 26: 397-414.

Jensen MC (1993) The modern industrial revolution, exit, and the failure of internal control systems. The Journal of Finance 48: 831-880.

Jensen MC. (1986). Agency costs of free cash flow, corporate finance, and takeovers. The American Economic Review 76:323-329.

Kazanjian RK (1988) Relation of dominant problems to stages of growth in technology-based new ventures. Academy of Management Journal 31: 257-279.

Klein A (1998) Firm performance and board committee structure. The Journal of Law and Economics 41: 275-304. 
Laux C and Laux V (2009) Board committees, CEO compensation, and earnings management. The Accounting Review 84: 869-891.

Lehn KM, Patro S and Zhao M (2009) Determinants of the size and composition of US corporate boards: 1935-2000. Financial Management 38: 747-780.

Linck JS, Netter JM and Yang T (2008) The determinants of board structure. Journal of Financial Economics 87: 308-328.

Masulis RW, Wang C and Xie F (2012) Globalizing the boardroom - The effects of foreign directors on corporate governance and firm performance. Journal of Accounting and Economics 53: 527-554.

Miller D and Friesen PH (1980) Momentum and revolution in organizational adaptation. Academy of Management Journal 23: 591-614.

Miller D and Friesen PH (1984) A longitudinal study of the corporate life cycle. Management Science 30: 1161-1183.

Monem RM (2013) Determinants of board structure: Evidence from Australia. Journal of Contemporary Accounting and Economics 9: 33-49.

Monks R and Minow N (2004) Corporate Governance (3rd ed.): Blackwell Publishing.

O'Connor T and Byrne J (2015).Governance and the corporate life-cycle. International Journal of Managerial Finance 11: 23-43.

Perrault E and McHugh P (2015) Toward a life cycle theory of board evolution: Considering firm legitimacy. Journal of Management and Organization 21: 627-649.

Petersen MA (2009) Estimating standard errors in finance panel data sets: Comparing approaches. Review of Financial Studies 22: 435-480.

Petkova AP, Rindova VP and Gupta AK (2008) How can new ventures build reputation and quest? An exploratory study. Corporate Reputation Review 11: 320-334.

Pfeffer JS and Salancik G (1978) The external control of organizations: a resource dependence perspective. Harper \& Row.

Prevost AK, Rao RP and Hossain M (2002) Board composition in New Zealand: An agency perspective. Journal of Business Finance and Accounting 29: 731-760.

Quinn RE and Cameron K (1983) Organizational life cycles and shifting criteria of effectiveness: Some preliminary evidence. Management Science 29: 33-51.

Raheja CG (2005) Determinants of board size and composition: A theory of corporate boards. Journal of Financial and Quantitative Analysis 40: 283-306.

Richardson S (2006) Over-investment of free cash flow. Review of Accounting Studies 11: 159-189.

Robbins DK and Pearce JA (1992) Turnaround: Retrenchment and recovery. Strategic Management Journal 13: 287-309.

Song F and Thakor AV (2006) Information control, career concerns, and corporate governance. The Journal of Finance 61: 1845-1896.

Stiles P and Taylor B (2001) Boards at work: How directors view their roles and responsibilities: How directors view their roles and responsibilities. OUP Oxford.

Sutton RI, Eisenhardt KM and Jucker JV (1986) Managing organizational decline: Lessons from Atari. Organizational Dynamics 14: 17-29.

Withers MC, Hillman AJ and Cannella AA (2012) A multidisciplinary review of the director selection literature. Journal of Management 38: 243-277. 
Table 1. Descriptive statistics and industry breakdown. Panel A: Descriptive statistics

\begin{tabular}{llllllll}
\hline & Variables & $\mathrm{N}$ & Mean & SD & $25 \%$ & Median & $75 \%$ \\
\hline Life cycle & INTRO & 11,251 & 0.325 & 0.468 & 0.000 & 0.000 & 1.000 \\
measures & GROWTH & 11,251 & 0.195 & 0.396 & 0.000 & 0.000 & 0.000 \\
& MATURE & 11,251 & 0.263 & 0.440 & 0.000 & 0.000 & 1.000 \\
& SHAKE-OUT & 11,251 & 0.131 & 0.337 & 0.000 & 0.000 & 0.000 \\
& DECLINE & 11,251 & 0.087 & 0.282 & 0.000 & 0.000 & 0.000 \\
Director & ADVDIR & 11,251 & 0.486 & 0.318 & 0.250 & 0.400 & 0.667 \\
characteristics & ADVDIR_IND & 11,251 & 0.259 & 0.270 & 0.000 & 0.200 & 0.400 \\
& ADVDIR_EXEC & 11,251 & 0.294 & 0.177 & 0.167 & 0.250 & 0.400 \\
& MONDIR & 11,251 & 0.290 & 0.269 & 0.000 & 0.250 & 0.500 \\
& MONDIR/ADVDIR & 10,289 & 0.915 & 1.164 & 0.000 & 0.500 & 1.333 \\
& BOTHDIR & 11,251 & 0.173 & 0.270 & 0.000 & 0.000 & 0.375 \\
& BSIZE & 11,251 & 6.018 & 2.213 & 4.000 & 6.000 & 7.000 \\
Control & INDPEN & 11,251 & 0.706 & 0.177 & 0.600 & 0.750 & 0.833 \\
variables & SIZE & 11,251 & 16.577 & 4.628 & 15.810 & 17.520 & 19.180 \\
& LEV & 11,251 & 0.108 & 0.189 & 0.000 & 0.012 & 0.178 \\
& MTB & 11,251 & 2.678 & 3.854 & 0.870 & 1.630 & 3.100 \\
& PPE & 11,251 & 0.352 & 0.351 & 0.051 & 0.238 & 0.574 \\
\hline
\end{tabular}

Panel B: Industry distribution

\begin{tabular}{|c|c|c|c|c|c|}
\hline Industry & GICS Industry sector & Observations & Percentages & $\begin{array}{l}\text { ASX } \\
\text { Observations }\end{array}$ & $\begin{array}{l}\text { ASX } \\
\text { percentages }\end{array}$ \\
\hline 10 & Energy & 1,428 & $12.69 \%$ & 2,876 & $13.55 \%$ \\
\hline 15 & Materials & 3,712 & $32.99 \%$ & 7,838 & $36.93 \%$ \\
\hline 20 & Industrials & 1,783 & $15.85 \%$ & 2,693 & $12.69 \%$ \\
\hline 25 & Consumer Discretionary & 1,560 & $13.87 \%$ & 2,249 & $10.60 \%$ \\
\hline 30 & Consumer Staples & 491 & $4.36 \%$ & 810 & $3.82 \%$ \\
\hline 35 & Health Care & 1,004 & $8.92 \%$ & 1,889 & $8.90 \%$ \\
\hline 45 & Information Technology & 860 & $7.64 \%$ & 2,112 & $9.95 \%$ \\
\hline 50 & Telecommunication Services & 252 & $2.24 \%$ & 374 & $1.76 \%$ \\
\hline \multirow[t]{2}{*}{55} & Utilities & 161 & $1.43 \%$ & 384 & $1.81 \%$ \\
\hline & Total & 11,251 & $100.00 \%$ & 21,225 & $100.00 \%$ \\
\hline
\end{tabular}

Notes: INTRO is an indicator variable coded 1 if a particular firm-year observation is in the 'introduction' stage of the firm life cycle. GROWTH, MATURE, SHAKE-OUT, and DECLINE are defined accordingly. ADVDIR is the ratio of number of advisory directors to total board size. ADVDIR_IND is the ratio of number of independent advisory detectors to total board size. ADVDIR_EXEC is the ratio of number of executive advisory directors excluding the CEO to total board size. MONDIR is the ratio of number of independent directors who are members of either $\mathrm{AC}$ or $\mathrm{RC}$ or both, to total board size. MONDIR/ADVDIR is the ratio of the total numbers of monitoring directors to advisory directors. The number of firm-year observations for this variable drops down to 10,289 , as 962 observations had no advisory directors. BOTHDIR is the ratio of the number of directors with both advisory and monitoring expertise to the total board size. BSIZE is the number of directors on the board. INDPEN is the ratio of number of independent directors on the board to total board size. SIZE is the natural logarithm of total assets of the firm at the end of the fiscal year. LEV is the ratio of long-term debt to total assets. MTB is market value of equity divided by book value of equity. PPE is the ratio of property, plant, and equipment to total assets. 
Table 2: Life cycle-wise mean difference of advisory, monitoring and both advisory and monitoring directors: HSD-test.

\begin{tabular}{|c|c|c|c|c|}
\hline \multirow{2}{*}{ Estimates } & \multicolumn{2}{|c|}{ Group means } & \multirow{2}{*}{$\begin{array}{c}\text { Mean } \\
\text { differences }\end{array}$} & \multirow{2}{*}{ HSD-test $^{\mathrm{a}}$} \\
\hline & (Stage 1) & (Stage 2) & & \\
\hline & INTRO & GROWTH & & \\
\hline ADVDIR & 0.597 & 0.392 & 0.204 & $28.94 *$ \\
\hline MONDIR & 0.240 & 0.335 & 0.095 & $15.21 *$ \\
\hline \multirow[t]{2}{*}{ BOTHDIR } & 0.112 & 0.221 & 0.108 & $17.52 *$ \\
\hline & GROWTH & MATURE & & \\
\hline ADVDIR & 0.392 & 0.364 & 0.029 & $4.044 *$ \\
\hline MONDIR & 0.335 & 0.334 & 0.001 & 0.08 \\
\hline \multirow{2}{*}{ BOTHDIR } & 0.221 & 0.251 & 0.031 & $4.94 *$ \\
\hline & MATURE & SHAKE-OUT & & \\
\hline ADVDIR & 0.364 & 0.510 & 0.146 & $20.69 *$ \\
\hline MONDIR & 0.334 & 0.292 & 0.043 & $6.86^{*}$ \\
\hline \multirow[t]{2}{*}{ BOTHDIR } & 0.251 & 0.140 & 0.111 & $17.93 *$ \\
\hline & SHAKE-OUT & DECLINE & & \\
\hline ADVDIR & 0.510 & 0.611 & 0.102 & $14.38 *$ \\
\hline MONDIR & 0.292 & 0.238 & 0.053 & $8.64 *$ \\
\hline \multirow{2}{*}{ BOTHDIR } & 0.140 & 0.107 & 0.034 & $5.46^{*}$ \\
\hline & INTRO & MATURE & & \\
\hline ADVDIR & 0.597 & 0.364 & 0.233 & $32.98 *$ \\
\hline MONDIR & 0.240 & 0.334 & 0.094 & $15.12 *$ \\
\hline \multirow[t]{2}{*}{ BOTHDIR } & 0.112 & 0.251 & 0.139 & $22.46^{*}$ \\
\hline & INTRO & SHAKE-OUT & & \\
\hline ADVDIR & 0.597 & 0.510 & 0.087 & $12.30 *$ \\
\hline MONDIR & 0.240 & 0.292 & 0.052 & $8.26 *$ \\
\hline \multirow[t]{2}{*}{ BOTHDIR } & 0.112 & 0.140 & 0.028 & $4.53 *$ \\
\hline & INTRO & DECLINE & & \\
\hline ADVDIR & 0.597 & 0.611 & 0.015 & 2.081 \\
\hline MONDIR & 0.240 & 0.238 & 0.002 & 0.38 \\
\hline \multirow[t]{2}{*}{ BOTHDIR } & 0.112 & 0.107 & 0.006 & 0.93 \\
\hline & GROWTH & SHAKE-OUT & & \\
\hline ADVDIR & 0.392 & 0.510 & 0.118 & $16.64 *$ \\
\hline MONDIR & 0.335 & 0.292 & 0.043 & $6.95 *$ \\
\hline \multirow[t]{2}{*}{ BOTHDIR } & 0.221 & 0.140 & 0.080 & $12.99 *$ \\
\hline & GROWTH & DECLINE & & \\
\hline ADVDIR & 0.392 & 0.611 & 0.219 & $31.02 *$ \\
\hline MONDIR & 0.335 & 0.238 & 0.097 & $15.59 *$ \\
\hline \multirow[t]{2}{*}{ BOTHDIR } & 0.221 & 0.107 & 0.114 & $18.45^{*}$ \\
\hline & MATURE & DECLINE & & \\
\hline ADVDIR & 0.364 & 0.611 & 0.248 & $35.06 *$ \\
\hline MONDIR & 0.334 & 0.238 & 0.097 & $15.50 *$ \\
\hline BOTHDIR & 0.251 & 0.107 & 0.145 & $23.39 *$ \\
\hline
\end{tabular}

Notes: ${ }^{\text {a }}$ For the Tukey HSD (honest significant difference) pairwise comparisons studentized range critical value at $5 \%$ significance level is 3.858 .

The sample consists of 11,251 non-financial firm-year observations for the period 2001-2014. All the continuous variables are winsorised at the $1^{\text {st }}$ and $99^{\text {th }}$ percentiles to mitigate the influence of outliers. Life cycle is measured following the procedures proposed by Dickinson (2011). INTRO is an indicator variable coded 1 if a particular firm-year observation is in the 'introduction' stage of the firm life cycle. GROWTH, MATURE, SHAKE-OUT, and DECLINE are defined accordingly. ADVDIR is the ratio of number of advisory directors to total board size. MONDIR is the ratio of number of independent directors who are members of either AC or RC or both, to total board size. BOTHDIR is the ratio of the number of directors with both advisory and monitoring expertise to the total board size. 
Table 3. Correlation analysis.

\begin{tabular}{|c|c|c|c|c|c|c|c|c|c|c|c|c|c|c|c|c|}
\hline & {$[1]$} & {$[2]$} & {$[3]$} & {$[4]$} & {$[5]$} & {$[6]$} & [7] & [8] & [9] & {$[10]$} & [11] & {$[12]$} & {$[13]$} & [14] & {$[15]$} & [16] \\
\hline [1] INTRO & - & & & & & & & & & & & & & & & \\
\hline [2] GROWTH & -0.33 & - & & & & & & & & & & & & & & \\
\hline [3] MATURE & -0.41 & -0.32 & - & & & & & & & & & & & & & \\
\hline [4] SHAKE-OUT & -0.25 & -0.20 & -0.24 & - & & & & & & & & & & & & \\
\hline [5] DECLINE & -0.20 & -0.16 & -0.19 & -0.12 & - & & & & & & & & & & & \\
\hline [6] ADVDIR & 0.24 & -0.13 & -0.22 & 0.03 & 0.12 & - & & & & & & & & & & \\
\hline [7] ADVDIR_IND & 0.19 & -0.12 & -0.19 & 0.05 & 0.12 & 0.83 & - & & & & & & & & & \\
\hline [8] ADVDIR_EXEC & 0.13 & -0.04 & -0.09 & -0.02 & 0.02 & 0.21 & -0.23 & - & & & & & & & & \\
\hline [9] MONDIR & -0.13 & 0.08 & 0.09 & 0.00 & -0.05 & -0.56 & -0.49 & -0.21 & - & & & & & & & \\
\hline [10] BOTHDIR & -0.15 & 0.08 & 0.16 & -0.05 & -0.08 & -0.44 & -0.38 & -0.18 & -0.41 & - & & & & & & \\
\hline [11] SIZE & -0.32 & 0.19 & 0.24 & -0.02 & -0.11 & -0.22 & -0.19 & -0.07 & 0.15 & 0.09 & - & & & & & \\
\hline [12] LEV & -0.12 & 0.16 & 0.08 & -0.08 & -0.06 & -0.13 & -0.09 & -0.12 & 0.07 & 0.09 & 0.09 & - & & & & \\
\hline [13] MTB & 0.11 & -0.05 & -0.01 & -0.07 & 0.01 & 0.02 & 0.02 & 0.04 & -0.02 & -0.02 & -0.05 & -0.07 & - & & & \\
\hline [14] PPE & -0.20 & 0.14 & 0.21 & -0.08 & -0.11 & -0.14 & -0.09 & -0.13 & 0.12 & 0.06 & 0.27 & 0.25 & -0.09 & - & & \\
\hline [15] BSIZE & -0.18 & 0.10 & 0.19 & -0.06 & -0.09 & -0.12 & -0.04 & -0.27 & 0.06 & 0.14 & 0.31 & 0.18 & -0.03 & 0.20 & - & \\
\hline [16] INDPEN & -0.13 & 0.04 & 0.09 & 0.02 & -0.02 & -0.21 & 0.23 & -1.00 & 0.21 & 0.18 & 0.07 & 0.12 & -0.04 & 0.13 & 0.27 & - \\
\hline
\end{tabular}

Notes: This Table presents Pearson's correlation analysis based on the full sample size of 11,251 firm-year observations. Bold and italicized coefficients are significant at $\mathrm{p}<0.001$ (two-tailed tests). INTRO is an indicator variable coded 1 if a particular firm-year observation is in the 'introduction' stage of the firm life cycle. GROWTH, MATURE, SHAKE-OUT, and DECLINE are defined accordingly. ADVDIR is the ratio of number of advisory directors to total board size. ADVDIR_IND is the ratio of number of independent advisory detectors to total board size. ADVDIR_EXEC is the ratio of number of executive advisory directors excluding the CEO to total board size. MONDIR is the ratio of number of independent directors who are members of either AC or RC or both, to total board size. BOTHDIR is the ratio of the number of directors with both advisory and monitoring expertise to the total board size. SIZE is the natural logarithm of total assets of the firm at the end of the fiscal year. LEV is the ratio of long-term debt to total assets. MTB is market value of equity divided by book value of equity. PPE is the ratio of property, plant, and equipment to total assets. BSIZE is the number of directors on the board. INDPEN is the ratio of number of independent directors on the board to total board size. 
Table 4. Advisory directors and firm life cycle

\begin{tabular}{|c|c|c|c|c|}
\hline \multicolumn{5}{|c|}{$\begin{array}{r}\text { ADVDIR }_{\mathrm{it}}=\gamma_{0}+\sum_{\gamma=1}^{4} \mathrm{LC}_{-} \mathrm{DUM}_{\mathrm{it}}+\gamma_{5} \mathrm{SIZE}_{\mathrm{it}}+\gamma_{6} \mathrm{LEV}_{\mathrm{it}}+\gamma_{7} \mathrm{MTB}_{\mathrm{it}}+ \\
\text { INDUSTRY_FE }+ \text { YEAR_FE }+\varepsilon_{\mathrm{it}} \ldots \ldots \ldots \ldots . . .(1)\end{array}$} \\
\hline & & (1) & (2) & (3) \\
\hline Variables & Predicted sign & ADVDIR & ADVDIR_IND & ADVDIR_EXEC \\
\hline INTRO & + & $0.047 * * *$ & $0.037 * * *$ & $0.014 * * *$ \\
\hline \multirow{2}{*}{ GROWTH } & + & & $\begin{array}{l}{[3.47]} \\
0.004\end{array}$ & $\begin{array}{l}{[2.19]} \\
0007\end{array}$ \\
\hline & . & {$[0.57]$} & {$[0.59]$} & {$[1.54]$} \\
\hline \multirow[t]{2}{*}{ SHAKE-OUT } & + & $0.027 * *$ & $0.024 * *$ & $-0.019 * * *$ \\
\hline & & [2.19] & {$[2.52]$} & {$[-3.23]$} \\
\hline \multirow[t]{2}{*}{ DECLINE } & + & $0.054 * * *$ & $\mathbf{0 . 0 3 9} * * *$ & -0.011 \\
\hline & & {$[3.33]$} & {$[2.91]$} & {$[-1.46]$} \\
\hline \multirow[t]{2}{*}{ SIZE } & $?$ & $-0.058 * * *$ & $-0.057 * * *$ & 0.000 \\
\hline & & {$[-17.28]$} & {$[-20.28]$} & {$[0.06]$} \\
\hline \multirow[t]{2}{*}{ LEV } & + & 0.016 & 0.024 & $-0.005 * * *$ \\
\hline & & {$[0.66]$} & {$[1.25]$} & {$[-4.58]$} \\
\hline \multirow[t]{2}{*}{ MTB } & + & -0.002 & -0.001 & $-0.035 * * *$ \\
\hline & & {$[-1.46]$} & {$[-1.08]$} & {$[-4.17]$} \\
\hline \multirow[t]{2}{*}{ PPE } & - & $-0.042 * * *$ & $-0.036 * * *$ & $-0.031 * * *$ \\
\hline & & {$[-2.71]$} & {$[-2.82]$} & {$[-6.10]$} \\
\hline \multirow[t]{2}{*}{ BSIZE } & + & $0.027 * * *$ & $0.022 * * *$ & $-0.016^{* * *}$ \\
\hline & & [11.09] & {$[10.63]$} & {$[-17.73]$} \\
\hline \multirow[t]{2}{*}{ INDPEN } & - & $-0.238 * * *$ & $0.493 * * *$ & - \\
\hline & & {$[-6.91]$} & [19.09] & \\
\hline \multirow[t]{2}{*}{ Constant } & $?$ & $1.638 * * *$ & $0.905 * * *$ & $0.501 * * *$ \\
\hline & & {$[25.23]$} & {$[17.47]$} & {$[25.48]$} \\
\hline Industry FE & & Yes & Yes & Yes \\
\hline Year FE & & Yes & Yes & Yes \\
\hline Observations & & 11,251 & 11,251 & 11,251 \\
\hline Adj. $\mathrm{R}^{2}$ & & 0.26 & 0.32 & 0.10 \\
\hline
\end{tabular}

Notes: This table reports results from OLS regressions relating firm life cycle stages to the presence of advisory directors on the board for Australian listed industrial firms from 2001 to 2014. All specifications include year and industry fixed effects. Industries are defined at the 2-digit SIC level. Continuous variables are winsorised at their 1st and 99th percentiles. Robust $\mathrm{t}$-statistics in brackets $* * * \mathrm{p}<0.01, * * \mathrm{p}<0.05, * \mathrm{p}<0.10$. ADVDIR is the ratio of number of advisory directors to total board size. ADVDIR_IND is the ratio of number of independent advisory detectors to total board size. ADVDIR_EXEC is the ratio of number of executive advisory directors excluding the CEO to total board size. INTRO is an indicator variable coded 1 if a particular firm-year observation is in the 'introduction' stage of the firm life cycle. GROWTH, SHAKE-OUT, and DECLINE are defined accordingly. SIZE is the natural logarithm of total assets of the firm at the end of the fiscal year. LEV is the ratio of long-term debt to total assets. MTB is market value of equity divided by book value of equity. PPE is the ratio of property, plant, and equipment to total assets. BSIZE is the number of directors on the board. INDPEN is the ratio of number of independent directors on the board to total board size. 
Table 5. Monitoring directors and firm life cycle.

$$
\begin{aligned}
\text { MONDIR }_{\text {it }}= & \gamma_{0}+\sum_{\substack{\gamma=1 \\
\text { LC_DUM }}}^{4}+\gamma_{5} \mathrm{SIZE}_{\mathrm{it}}+\gamma_{6} \mathrm{LEV}_{\mathrm{it}}+\gamma_{7} \mathrm{MTB}_{\mathrm{it}}+\gamma_{8} \mathrm{PPE}_{\mathrm{it}}+\gamma_{9} \mathrm{BSIZE}_{\mathrm{it}}+\gamma_{10} \mathrm{INDPEN}_{\mathrm{it}}+ \\
& \text { INDUSTRY_FE }+ \text { YEAR_FE }+\varepsilon_{\mathrm{it}} \ldots \ldots \ldots \ldots \ldots \ldots \ldots \ldots(2)
\end{aligned}
$$

\begin{tabular}{|c|c|c|c|c|}
\hline Variables & Predicted sign & MONDIR & MONDIR/ADVDIR & BOTHDIR \\
\hline INTRO & - & $\begin{array}{l}-\mathbf{0 . 0 3 8} * * * * \\
{[-3.27]}\end{array}$ & $\begin{array}{l}-0.257 * * * \\
{[-5.38]}\end{array}$ & $\begin{array}{l}-0.028 * * \\
{[-2.25]}\end{array}$ \\
\hline GROWTH & - & $\begin{array}{l}0.009 \\
{[1.08]}\end{array}$ & $\begin{array}{l}0.015 \\
{[0.35]}\end{array}$ & $\begin{array}{l}-0.014 \\
{[-1.50]}\end{array}$ \\
\hline SHAKE-OUT & - & $\begin{array}{l}-0.020 * \\
{[-1.76]}\end{array}$ & $\begin{array}{l}-0.193 * * * \\
{[-3.96]}\end{array}$ & $\begin{array}{l}-0.028 * * \\
{[-2.41]}\end{array}$ \\
\hline DECLINE & - & $\begin{array}{l}-0.056 * * * \\
{[-3.85]}\end{array}$ & $\begin{array}{l}-0.290 * * * \\
{[-5.11]}\end{array}$ & $\begin{array}{l}-0.026 * \\
{[-1.76]}\end{array}$ \\
\hline SIZE & + & $\begin{array}{l}-0.000 \\
{[-0.45]}\end{array}$ & $\begin{array}{l}-0.002 \\
{[-0.63]}\end{array}$ & $\begin{array}{l}0.001 \\
{[1.04]}\end{array}$ \\
\hline LEV & + & $\begin{array}{l}0.052 * * * \\
{[3.82]}\end{array}$ & $\begin{array}{l}0.252^{* * * *} \\
{[4.61]}\end{array}$ & $\begin{array}{l}0.037 * * * \\
{[13.30]}\end{array}$ \\
\hline MTB & - & $\begin{array}{l}-0.010 \\
{[-0.45]}\end{array}$ & $\begin{array}{l}0.028 \\
{[0.34]}\end{array}$ & $\begin{array}{l}0.005 \\
{[0.23]}\end{array}$ \\
\hline PPE & + & $\begin{array}{l}0.050 * * * \\
{[3.46]}\end{array}$ & $\begin{array}{l}0.181 * * * \\
{[3.20]}\end{array}$ & $\begin{array}{l}-0.011 \\
{[-0.84]}\end{array}$ \\
\hline BSIZE & + & $\begin{array}{l}-0.007 * * * \\
{[-2.97]}\end{array}$ & $\begin{array}{l}-0.027 * * * \\
{[-3.22]}\end{array}$ & $\begin{array}{l}-0.010 * * * \\
{[-4.17]}\end{array}$ \\
\hline INDPEN & + & $\begin{array}{l}0.314 * * * \\
{[12.12]}\end{array}$ & $\begin{array}{l}1.378 * * * \\
{[14.53]}\end{array}$ & $\begin{array}{l}0.158 * * * \\
{[6.96]}\end{array}$ \\
\hline Constant & & $\begin{array}{l}-0.035 \\
{[-0.80]}\end{array}$ & $\begin{array}{l}-0.636 * * * \\
{[-3.58]}\end{array}$ & $\begin{array}{l}-0.667 * * * \\
{[-13.17]}\end{array}$ \\
\hline Industry FE & & YES & YES & YES \\
\hline Year FE & & YES & YES & YES \\
\hline Obs. & & 11,251 & 10,289 & 11,251 \\
\hline Adj. $R^{2}$ & & 0.0 .09 & 0.09 & 0.19 \\
\hline
\end{tabular}

(1)

Notes: This table reports results from OLS regressions relating firm life cycle stages to the presence of monitoring directors on the board of Australian listed industrial firms from 2001 to 2014. All specifications include year and industry fixed effects. Industries are defined at the 2-digit SIC level. Continuous variables are winsorised at their 1st and 99th percentiles. Robust t-statistics in brackets. ${ }^{* *} \mathrm{p}<0.01, * * \mathrm{p}<0.05, * \mathrm{p}<0.10$. Variable definitions are in Table 1. MONDIR is the ratio of number of independent directors who are members of either AC or RC or both, to total board size. MONDIR/ADVDIR is the ratio of the total numbers of monitoring directors to advisory directors. The number of firm-year observations for this variable drops down to 10,289, as 962 observations had no advisory directors. BOTHDIR is the ratio of the number of directors with both advisory and monitoring expertise to the total board size. SIZE is the natural logarithm of total assets of the firm at the end of the fiscal year. LEV is the ratio of long-term debt to total assets. MTB is market value of equity divided by book value of equity. PPE is the ratio of property, plant, and equipment to total assets. BSIZE is the number of directors on the board. INDPEN is the ratio of number of independent directors on the board to total board size. 